\title{
Enantioselective Addition of Diethylzinc to Benzaldehyde Catalyzed by an Organometallic Ti(IV) Compound and a Xylose Derivative
}

\author{
José Parada,* Juan Herrera and A. Pedraza \\ Departamento de Química Inorgánica y Analítica, Facultad de Ciencias Químicas y Farmacéuticas, \\ Universidad de Chile, Casilla 233, Santiago 1, Chile
}

\begin{abstract}
Um derivado da D-xylose, 1,2-O-isopropilideno- $\alpha$-D-xilofuranose (1), com Ti $\left(\mathrm{O}^{\mathrm{i}} \mathrm{Pr}\right)_{4}$ foi usado como catalisador chiral na alquilação assimétrica do benzaldeído com dietilzinco (Et Zn) para produção de 1-fenil-1-propanol em alto rendimento (conversão de 90\%) e enantiosseletividade moderada $(45 \%$ ee $(S))$. As condições ótimas (conversão e enantiosseletividade) para o sistema catalítico formado por $\mathbf{1}$ e Ti(IV) foram $10.0 \mathrm{~mol} \%$ de $\mathbf{1}$ e 1 equivalente de Ti(IV) com relação ao benzaldeído em $\mathrm{CH}_{2} \mathrm{Cl}_{2}$ como solvente, a temperatura ambiente. $\mathrm{Na}$ alquilação assimétrica do benzaldeído com $\mathrm{Et}_{2} \mathrm{Zn}$, o composto 1 em quantidade sub-estequiométrica com $\mathrm{Ti}\left(\mathrm{O}^{\mathrm{i}} \mathrm{Pr}\right)_{4}$ forma um catalisador quiral do tipo Ti(IV)-açúcar, o que assegura uma conversão com bom rendimento e a enantiosseletividade da reação.
\end{abstract}

A derivative of D-xylose, 1,2-O-isopropylidene- $\alpha$-D-xylofuranose (1), with $\operatorname{Ti}\left(\mathrm{O}^{\mathrm{i}} \mathrm{Pr}\right)_{4}$ was used as a chiral catalyst in the asymmetric alkylation of benzaldehyde with diethylzinc ( $\left.\mathrm{Et}_{2} \mathrm{Zn}\right)$ for the high-yield production ( $90 \%$ conversion) and moderate enantioselectivity (45\% ee $(S)$ ) of 1-phenyl-1-propanol. Optimum conditions (conversion and enantioselectivity) for the catalytic system formed by 1 and Ti(IV) were $10.0 \mathrm{~mol} \%$ of $\mathbf{1}$ and 1 equivalent of Ti(IV) with respect to benzaldehyde in $\mathrm{CH}_{2} \mathrm{Cl}_{2}$ as a solvent, at room temperature. In the asymmetric alkylation of benzaldehyde with $\mathrm{Et}_{2} \mathrm{Zn}$ compound $\mathbf{1}$ in substoichiometric amount with $\mathrm{Ti}\left(\mathrm{O}^{\mathrm{i}} \mathrm{Pr}\right)_{4}$ forms a chiral catalyst of the Ti(IV)-sugar type that ensures the good-yield conversion and the enantioselectivity of the reaction.

Keywords: diethylzinc, xylose derivative, Ti(IV), titanium

\section{Introduction}

1,2 enantioselective addition of organometallic compounds (asymmetric alkylation) to prochiral aldehydes or ketones is currently one of the most important synthetic procedures to obtain chiral alcohols, ${ }^{1-3}$ which are natural biologically active compounds ${ }^{4}$ and are also very useful synthetic precursors, as in the syntheses of some drugs and insecticides. ${ }^{5,6}$

1,2 addition of dialkylzinc to aldehydes and ketones is extremely slow. ${ }^{7}$ However, it is accelerated by substoichiometric amounts of such chiral substances as aminoalcohols and diols, including some carbohydrate derivatives ${ }^{8,9}$ In these conditions, a mixed catalyst is formed between $\mathrm{Zn}(\mathrm{II})$, the chiral ligand, and the carbonyl compound, which facilitates attack by the alkyl group (R-) on the prochiral carbonyl compound, preferentially on one of its faces.

*e-mail: jparada@ciq.uchile.cl
After hydrolysis the alcohol is obtained, enriched in one configuration $(R$ or $S$ ).

Recent studies have shown that when the ligand is a chiral diol with a Ti(IV) compound (for example $\left.\mathrm{Ti}\left(\mathrm{O}^{\mathrm{i}} \mathrm{Pr}\right)_{4}\right)$, the reaction occurs in high yield and with high enantioselectivity. ${ }^{7-9}$

The purpose of this paper was to study catalysis by the derivative of $\mathrm{D}$-xylose 1 and $\mathrm{Ti}(\mathrm{O} \mathrm{Pr})_{4}$ in the asymmetric alkylation of benzaldehyde with diethylzinc to obtain, after acid hydrolysis, 1-phenyl-1-propanol in high yield and with moderate enantioselectivity.

\section{Results and Discussion}

\section{1,2 Enantioselective addition of diethylzinc to benzaldehyde catalyzed by an organometallic Ti(IV) compound and derivative 1}

We found that the $\mathbf{1}$ and Ti(IV) catalytic system acts optimally in the mixture of $0.1 \mathrm{~mL}$ ( $1 \mathrm{mmol}$ ) of anhydrous 
benzaldehyde and $3 \mathrm{~mL}$ ( $3 \mathrm{mmol})$ of $\mathrm{Et}_{2} \mathrm{Zn}$ in $2.5 \mathrm{~mL}$ of anhydrous $\mathrm{CH}_{2} \mathrm{Cl}_{2}$ in a Schlenk tube under nitrogen at room temperature with constant stirring. Under these conditions, a sufficient amount of 1-phenyl-1-propanol was obtained for its characterization and quantification by gas chromatography (GC). From the area under the chromatogram peaks we determined the yield (conversion\% of benzaldehyde into 1-phenyl-1-propanol) and the enantioselectivity $(e e \%)$ of the reactions (Tables 1 and 2) and the products were identified by ${ }^{1} \mathrm{H}-\mathrm{NMR}$. The predominant configuration was determined for each catalytic system. ${ }^{11,12}$

To optimize the concentration conditions of the catalytic system of 1 and $\mathrm{Ti}(\mathrm{IV})$, several reactions were carried out by using mixtures of $\mathbf{1}$ in variable substoichiometric amounts $(2.5,5.0,10.0$, and $20.0 \mathrm{~mol} \%)$ with respect to benzaldehyde with $1 \mathrm{mmol}$ of $\mathrm{Ti}\left(\mathrm{O}^{i} \mathrm{Pr}\right)_{4}$, because with concentrations of that order other authors ${ }^{6,12}$ had achieved good results with other chiral catalysts and we had earlier obtained promising results with them..$^{14,15}$

A high conversion of benzaldehyde into 1-phenyl-1propanol was obtained after a $6 \mathrm{~h}$ reaction, with Ti(IV) and $10.0 \mathrm{~mol} \%$ of 1 with respect to benzaldehyde at room temperature (entry 8 in Table 1), indicating that the catalyst formed in situ in this reaction is effective with small amounts of $\mathbf{1}$ (Table 1). After an $18 \mathrm{~h}$ reaction, maximum conversion of benzaldehyde into 1-phenyl-1-propanol was obtained with $10.0 \mathrm{~mol} \%$ of $\mathbf{1}$ (entry 12 in Table 1). After a $24 \mathrm{~h}$ reaction, there was decreased conversion of benzaldehyde into 1-phenyl-1-propanol (entries 14 and 15 in Table 1), because of decomposition of 1-phenyl-propanol after 18 hours. ${ }^{11}$

The optical rotation $\left(\alpha^{\circ}\right)$ of all the asymmetric alkylation products with 1 had a negative sign, (-), indicating that the 1-phenyl-1-propanol preferably has the $S$ configuration (Tables 1 and 2). ${ }^{13}$

Enantioselectivity $(45 \% e e)$ was achieved after a $6 \mathrm{~h}$ reaction with $10.0 \mathrm{~mol} \%$ of $\mathbf{1}$ (entry 8 in Table 1). A larger amount of $\mathbf{1}(20 \%)$ did not increase enantioselectivity significantly (entry 9 in Table 1) probably because the sugar derivative $\mathbf{1}$ acts with Ti(IV) forming a chiral catalyst of the Ti(IV)-sugar type with an optimum amount of $\mathbf{1}$,

Table 1. Asymmetric alkylation of benzaldehyde with $\mathrm{Et}_{2} \mathrm{Zn}$ catalyzed by carbohydrate derivative $\mathbf{1}$ and $\mathrm{Ti}\left(\mathrm{O}^{\mathrm{i}} \mathrm{Pr}\right)_{4}^{\mathrm{a}}$

\begin{tabular}{|c|c|c|c|c|}
\hline Entry & $\begin{array}{l}\text { Percentage } \\
\text { Conversion }^{\mathrm{c}}\end{array}$ & $\begin{array}{c}\% e e^{\mathrm{d}} \\
(\text { Config. })^{\mathrm{e}}\end{array}$ & $\begin{array}{c}\mathrm{mol} \% \\
\text { of } 1^{\mathrm{b}}\end{array}$ & $\begin{array}{l}\text { Reaction } \\
\text { time / h }\end{array}$ \\
\hline 1 & 15 & $2(S)$ & 0 & 3 \\
\hline 2 & 55 & $17(S)$ & 2.5 & 3 \\
\hline 3 & 60 & $20(S)$ & 5.0 & 3 \\
\hline 4 & 80 & $33(S)$ & 10.0 & 3 \\
\hline 5 & 83 & $31(S)$ & 20.0 & 3 \\
\hline 6 & 53 & $20(S)$ & 2.5 & 6 \\
\hline 7 & 63 & $30(S)$ & 5.0 & 6 \\
\hline 8 & 85 & $45(S)$ & 10.0 & 6 \\
\hline 9 & 80 & $48(S)$ & 20.0 & 6 \\
\hline 10 & 50 & $10(S)$ & 2.5 & 18 \\
\hline 11 & 45 & $20(S)$ & 5.0 & 18 \\
\hline 12 & 90 & $17(S)$ & 10.0 & 18 \\
\hline 13 & 29 & $26(S)$ & 20.0 & 18 \\
\hline 14 & 63 & $40(S)$ & 10.0 & 24 \\
\hline 15 & 70 & $33(S)$ & 20.0 & 24 \\
\hline
\end{tabular}

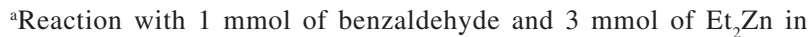
the presence of $1 \mathrm{mmol}$ of $\mathrm{Ti}(\mathrm{OiPr})_{4} \cdot{ }^{b} \mathrm{Mol}$ percentages referred to benzaldehyde. ${ }^{~}$ Determined by GC. ${ }^{\mathrm{d}}$ Determined by GC with $\beta$-DEX 120 column. ${ }^{e}$ Determined from optical rotation.

Table 2. Results of the asymmetric alkylation of benzaldehyde with $\mathrm{Et}_{2} \mathrm{Zn}$ catalyzed by carbohydrate derivative $\mathbf{1}$ and a metal ion after $6 \mathrm{~h}$ of reaction ${ }^{\mathrm{a}, \mathrm{b}}$

\begin{tabular}{|c|c|c|c|c|c|}
\hline Entry & Porcentage conversion ${ }^{\mathrm{c}}$ & $e e \%^{\mathrm{d}}(\text { config. })^{\mathrm{e}}$ & Metal center & Solvent & $\mathrm{T} /{ }^{\circ} \mathrm{C}$ \\
\hline $1^{\mathrm{a}}$ & 43 & $15(S)$ & $\operatorname{Ti}(\mathrm{IV})^{\mathrm{a}}$ & $\mathrm{CH}_{2} \mathrm{Cl}_{2}$ & -20 \\
\hline $2^{\mathrm{a}}$ & 35 & $40(S)$ & $\operatorname{Ti}(\mathrm{IV})^{\mathrm{a}}$ & $\mathrm{CH}_{2} \mathrm{Cl}_{2}$ & 0 \\
\hline $3^{\mathrm{a}}$ & 63 & $30(S)$ & $\operatorname{Ti}(\mathrm{IV})^{\mathrm{a}}$ & $\mathrm{CH}_{2} \mathrm{Cl}_{2}$ & 20 \\
\hline $1^{\mathrm{b}}$ & 43 & $50(S)$ & $\operatorname{Ti}(\mathrm{IV})^{\mathrm{b}}$ & $\mathrm{CH}_{2} \mathrm{Cl}_{2}$ & -20 \\
\hline $2^{\mathrm{b}}$ & 70 & $40(S)$ & $\operatorname{Ti}(\mathrm{IV})^{\mathrm{b}}$ & $\mathrm{CH}_{2} \mathrm{Cl}_{2}$ & 0 \\
\hline $3^{\mathrm{b}}$ & 85 & $45(S)$ & $\operatorname{Ti}(\mathrm{IV})^{\mathrm{b}}$ & $\mathrm{CH}_{2} \mathrm{Cl}_{2}$ & 20 \\
\hline $4^{\mathrm{b}}$ & 66 & $35(S)$ & $\operatorname{Ti}(\mathrm{IV})^{\mathrm{b}}$ & THF & 20 \\
\hline $5^{\mathrm{b}}$ & 90 & $50(S)$ & $\operatorname{Ti}(\mathrm{IV})^{\mathrm{b}}$ & Toluene & 20 \\
\hline 6 & 70 & $17(S)$ & $\mathrm{Co}(\mathrm{II})^{\mathrm{b}}$ & $\mathrm{CH}_{2} \mathrm{Cl}_{2}$ & 20 \\
\hline 7 & 13 & $3(S)$ & $\mathrm{Cu}(\mathrm{II})^{\mathrm{b}}$ & $\mathrm{CH}_{2} \mathrm{Cl}_{2}$ & 20 \\
\hline
\end{tabular}

Reaction with ${ }^{\mathrm{a}} 5.0$ and ${ }^{\mathrm{b}} 10.0 \mathrm{~mol} \%$ of 1 with respect to $1 \mathrm{mmol}$ de benzaldehyde and $3 \mathrm{mmol} \mathrm{Et} \mathrm{Zn}$ in the presence of 1 mmol of metal ion ${ }^{\mathrm{c}} \mathrm{determined}$ by GC. ${ }^{\mathrm{D} D e t e r m i n e d ~ b y ~ G C ~ w i t h ~} \beta$-DEX 120 column. ${ }^{\mathrm{e}}$ Determined from optical rotation. 


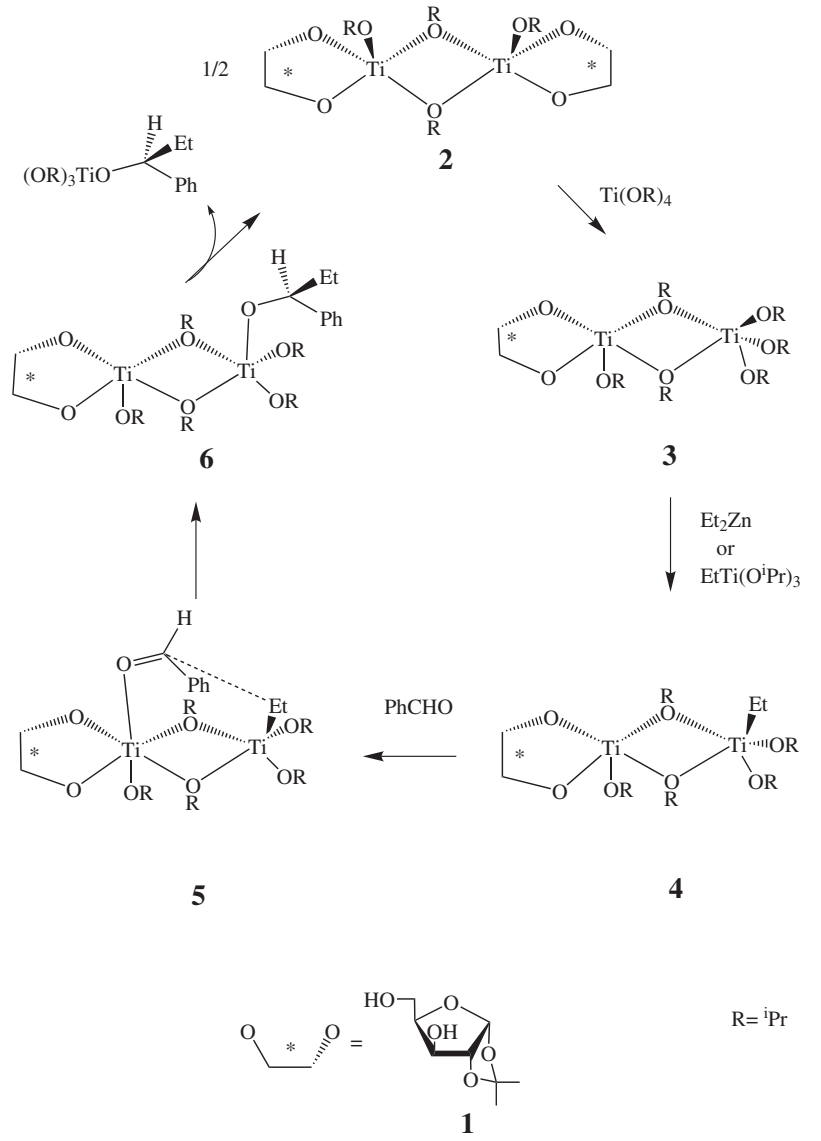

Scheme 1. in this case $10.0 \mathrm{~mol} \%$ of that derivative with respect to benzaldehyde.

Lowering the temperature from room temperature to $0{ }^{\circ} \mathrm{C}$ and $-20^{\circ} \mathrm{C}$ decreased conversion of benzaldehyde into 1-phenyl-1-propanol (Table 2), but the lower temperature did not significantly increase the enantioselectivity (ee\%) of the reaction (Table 2). This is probably because the determining step in the asymmetric reaction is controlled by the structure of the metal-sugar type chiral catalyst, which should not depend very much on temperature. . $^{7,8,11,12}$

The use of other solvents such as toluene or THF rather than $\mathrm{CH}_{2} \mathrm{Cl}_{2}$ produced no significant improvement in conversion or enantioselectivity (Table 2). Thus, most reactions were carried out in $\mathrm{CH}_{2} \mathrm{Cl}_{2}{ }^{11}$.

In order to test the catalytic capacity of $\mathbf{1}$ with other metal ions, alkylation of benzaldehyde with $\mathrm{ZnEt}_{2}$ was studied by using $\mathrm{Co}(\mathrm{II})$ or $\mathrm{Cu}(\mathrm{II})$. The reaction was carried out with $\mathrm{Co}(\mathrm{II})$ or $\mathrm{Cu}(\mathrm{II})$ acetylacetonate $\left(\mathrm{Co}(\mathrm{acac})_{2}\right.$ or $\left.\mathrm{Cu}(\mathrm{acac})_{2}\right)$ (Table 2) instead of $\mathrm{Ti}\left(\mathrm{O}^{\mathrm{i}} \mathrm{Pr}\right)_{4}$. Conditions for the reactions with these ions were the same as used with the Ti(IV) and 1 system. The catalytic system of $\mathrm{Co}$ (II) and $\mathbf{1}$ gave lower conversion and enantioselectivity of 1-phenyl1-propanol than those achieved with Ti(IV) and 1 (Table 2). The $\mathrm{Cu}(\mathrm{II})$ and 1 system did not catalyze the reaction. These results indicate that the metal-sugar type catalyst in the asymmetric alkylation must be an octahedral complex

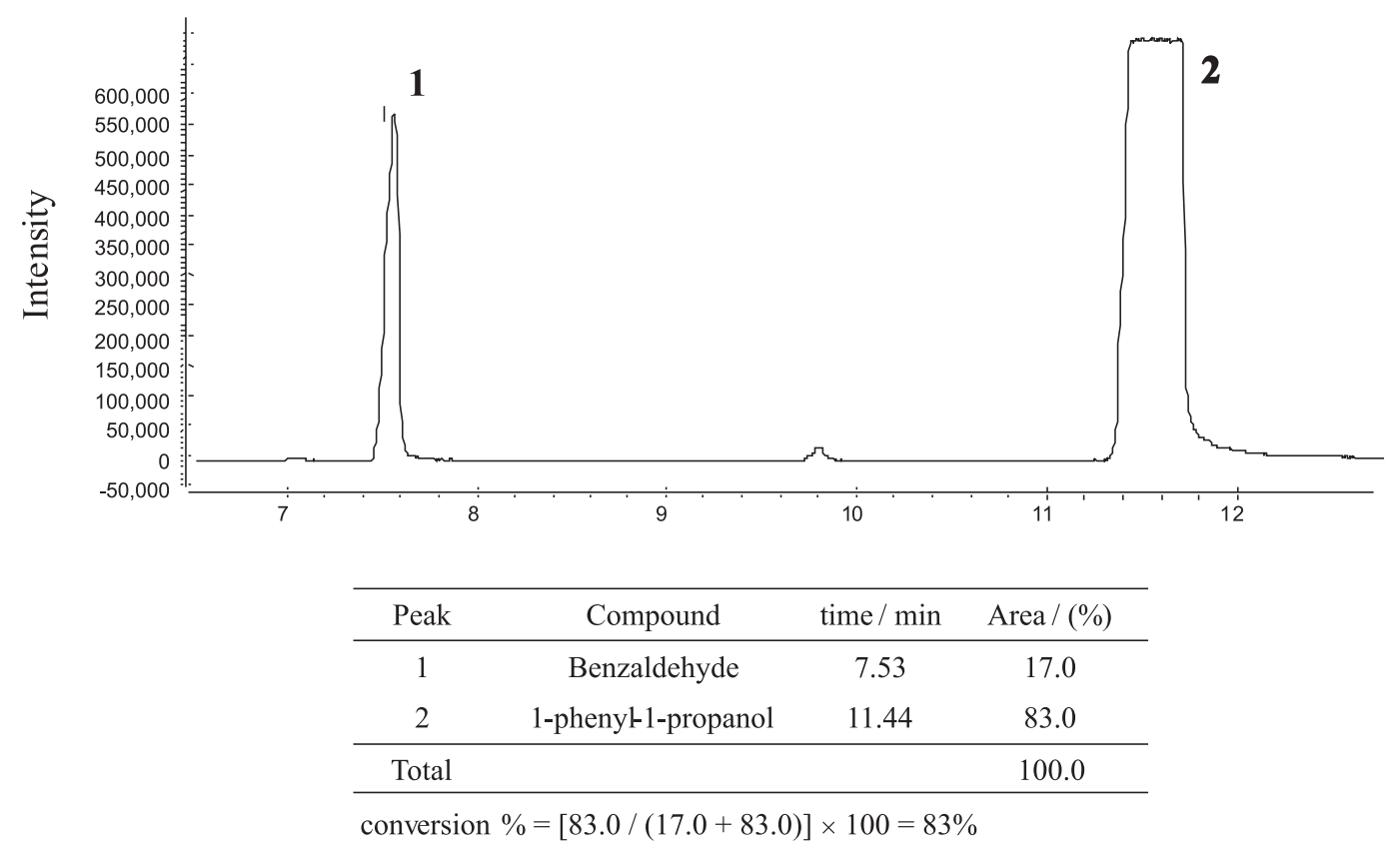

Figure 1. Chromatogram in column methyl silicone gum $5 \mathrm{~m} \times 0.53 \mathrm{~mm} \times 2.65 \mu \mathrm{m}$ of the asymmetric alkylation of benzaldehyde with Et $\mathrm{Zn}$ in the presence of $10.0 \mathrm{~mol} \%$ of $\mathbf{1}$. Entry 5, Table 1 . Conditions in which the chromatogram was performed: Injector temperature, $250{ }^{\circ} \mathrm{C}$; detector temperature, $250{ }^{\circ} \mathrm{C}$; pressure, $10 \mathrm{psi}$; initial temperature, $100^{\circ} \mathrm{C}$; initial time, $5 \mathrm{~min}$; rate, $20^{\circ} \mathrm{C} \mathrm{min}^{-1}$; final temperature, $180{ }^{\circ} \mathrm{C}$; final time, $18 \mathrm{~min}$ (top). Retention times (min) and peak areas of benzaldehyde and $S$ - and $R$-1-phenyl-1-propanol present in the chromatogram are tabulated. Calculation of conversion $\%$ from these areas is shown at the bottom. 


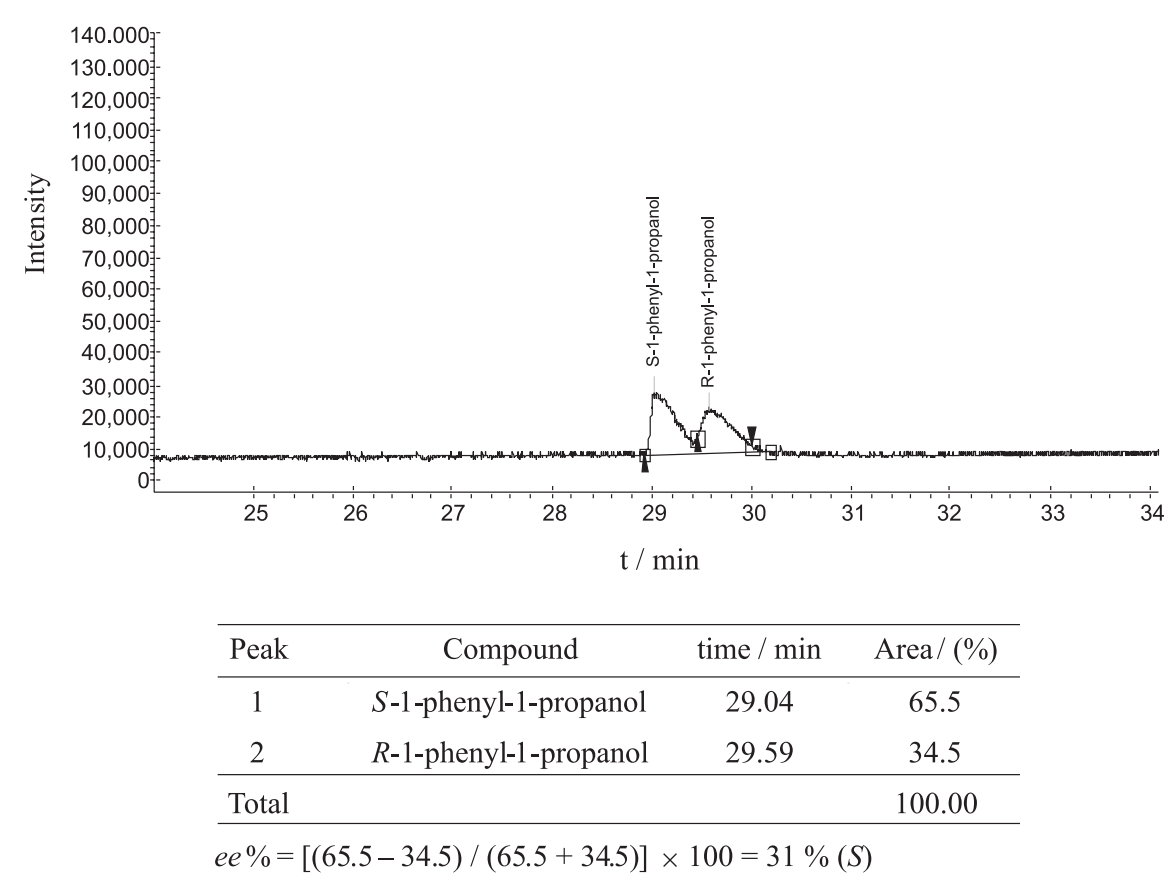

Figure 2. Chromatogram in column Supelco $\beta$-Dex $120 \mathrm{de} 30 \mathrm{~m} \times 0.25 \mathrm{~mm} \times 0.25 \mu \mathrm{m}$ of the asymmetric alkylation of benzaldehyde with Et $\mathrm{Zn}$ in the presence of $10.0 \mathrm{~mol} \%$ of $\mathbf{1}$. Entry 5 , Table 1 . Conditions in which the chromatogram was performed: Injector temperature, $250^{\circ} \mathrm{C}$; detector temperature, $250{ }^{\circ} \mathrm{C}$; pressure, $10 \mathrm{psi}$; initial temperature, $100{ }^{\circ} \mathrm{C}$; initial time, $10 \mathrm{~min}$; rate, $1{ }^{\circ} \mathrm{C} \mathrm{min}{ }^{-1}$; final temperature, $140{ }^{\circ} \mathrm{C}$; final time, $4 \mathrm{~min}$ (top). Retention times ( $\mathrm{min}$ ) and peak areas of benzaldehyde and $S$ - and $R$-1-phenyl-1-propanol present in the chromatogram are tabulated. Calculation of $e e \%$ from these areas is shown at the bottom.

as obtained with $\mathrm{Ti}(\mathrm{IV})$ and $\mathrm{Co}$ (II), and not a square planar one formed mainly by $\mathrm{Cu}$ (II).

Therefore, optimum catalytic conditions in asymmetric alkylation are with $10 \mathrm{~mol} \%$ of $\mathbf{1}$ with respect to benzaldehyde, and $\mathrm{Ti}(\mathrm{IV})$ as the metal reaction center in $\mathrm{CH}_{2} \mathrm{Cl}_{2}$ (entry 8 in Table 1 ). ${ }^{11}$

The conversion and enantioselectivity of the reaction in the presence of $\mathbf{1}$ and $\mathrm{Ti}\left(\mathrm{O}^{\mathrm{i}} \mathrm{Pr}\right)_{4}$ probably involve formation of a complex of the "Ti(IV)-sugar" type, allowing ethyl group (Et-) transfer preferentially to one of the faces of benzaldehyde, and favoring formation of the enantiomer with the $\mathrm{S}$ configuration of the product.

The possible mechanism for asymmetric alkyl addition is given in Scheme 1. The reaction of the xylose derivative 1 with 1 molar equiv. of $\mathrm{Ti}\left(\mathrm{O}^{i} \mathrm{Pr}\right)_{4}$ involves the dimeric complex 2, because $\mathrm{Ti}(\mathrm{O} \mathrm{Pr})_{4}$ reacts with $\mathbf{1}(1: 1)$ in $\mathrm{CH}_{2} \mathrm{Cl}_{2}$, giving $\left\{\left[\mathrm{Ti}(\mathrm{IV})(\mathbf{1})(\mathrm{O} \cdot \mathrm{Pr})_{2}\right] \cdot 2\left(\mathrm{CH}_{2} \mathrm{Cl}_{2}\right)\right\}_{2}(\mathrm{C} 36.26$ (36.80); H 5.48 (5.37); \%found (\%calculated)). Complex 2 further reacts with 1 molar equiv. of $\operatorname{Ti}\left(\mathrm{O}^{i} \mathrm{Pr}\right)_{4}$, giving another dimeric complex, 3. These dimeric complexes have been postulated in the literature on titanium catalysis of asymmetric alkylation. ${ }^{16-22,25}$ Complex 3 reacts with $\mathrm{Et}_{2} \mathrm{Zn}$ or with $\operatorname{EtTi}\left(\mathrm{O}^{i} \mathrm{Pr}\right)_{3}$, giving complex 4. $\mathrm{EtTi}\left(\mathrm{O}^{i} \mathrm{Pr}\right)_{3}$ can be generated from reaction of excess $\mathrm{Ti}\left(\mathrm{O}^{i} \mathrm{Pr}\right)_{4}$ with $\mathrm{Et}_{2} \mathrm{Zn}$, as described for similar catalytic systems. ${ }^{7,25}$ Complex 4 further reacts with $1 \mathrm{~mol}$ of benzaldehyde, giving complex
5. To achieve the $S$ configuration of the chiral alcohol, the attached Et- moves to the carbonyl carbon and the benzaldehyde oxygen probably moves simultaneously toward the second titanium center with the attached alkyl group, giving complex $\mathbf{6}$. Complex $\mathbf{6}$ gives complex $\mathbf{2}$. Regeneration of the starting complex 2 completes the catalytic cycle.

\section{Conclusions}

The presence of derivatives of $\mathrm{D}$-xylose (1) in a substoichiometric amount with $\mathrm{Ti}(\mathrm{O} \mathrm{Pr})_{4}$ in the asymmetric alkylation of benzaldehyde with $\mathrm{Et}_{2} \mathrm{Zn}$ forms a chiral catalyst of dimeric complexes 6 ensuring the conversion and enantioselectivity of the reaction. The best catalytic condition (conversion and enantioselectivity) was achieved with $10.0 \mathrm{~mol} \%$ of 1 with respect to benzaldehyde. The conversion and enantioselectivity achieved in the synthesis of the alcohol with $\mathbf{1}$ is due to the formation within the reaction system of dimeric complexes Ti(IV)sugar (Scheme 1), facilitating transfer of the ethyl group to one face of benzaldehyde. The intrinsic chiral properties of carbohydrate $\mathbf{1}$ are transmitted through the dimeric Ti(IV)-sugar type complexes formed during the synthesis of 1-phenyl-1-propanol, yielding preferably its $\mathrm{S}$ enantiomer. The catalytic efficiency of the dimeric 
Ti(IV)-sugar complexes in the asymmetric alkylation of benzaldehyde with diethylzinc is determined by their stability and rigidity.

\section{Experimental}

All reagents and solvents were analytical grade.

Enantioselective 1,2-addition of diethylzinc to benzaldehyde catalyzed by a Ti(IV) organometallic compound and a xylose derivative

Compound 1 (19 mg, 10.0 mol\% with respect to benzaldehyde) was placed in a dry $50 \mathrm{~mL}$ Schlenk tube, closed with a silicone stopper, and air was removed by purging three times with nitrogen and vacuum. The following were then added successively: $0.1 \mathrm{~mL}(1 \mathrm{mmol})$ benzaldehyde, $2.5 \mathrm{~mL}$ dichoromethane, $0.3 \mathrm{~mL}$ ( $1 \mathrm{mmol})$ $97 \%$ titanium(IV) isopropoxide, and finally $3 \mathrm{~mL}$ ( $3 \mathrm{mmol})$ of a $1 \mathrm{~mol} \mathrm{~L}^{-1}$ solution of $\mathrm{Et}_{2} \mathrm{Zn}$ in hexane.

The reaction proceeded with stirring for 3 hours at room temperature, and was stopped by adding a saturated solution of ammonium chloride (releasing ethane and forming a white precipitate of zinc oxide). The mixture was transferred to a separatory funnel, $10 \mathrm{~mL}$ of $2 \mathrm{~mol} \mathrm{~L}^{-1}$ $\mathrm{HCl}$ were added, and the product was extracted with three $10 \mathrm{~mL}$ portions of ethyl ether, dried with anhydrous $\mathrm{MgSO}_{4}$ and the ether was evaporated, yielding crude 1-phenyl-1propanol.

This general procedure was applied to all the catalytic reactions with different concentrations, solvents and reaction temperatures as shown in Tables 1 and 2 under Results and Discussion.

\section{Product analysis}

To analyze the products and determine percentage conversion, the sample, $0.4 \mu \mathrm{L}$, was injected into an HP 5890 series II gas chromatograph equipped with an Allchrom plus program and a methylsilicone-gum-type $5 \mathrm{~m} \times$ $0.53 \mathrm{~mm} \times 2.65 \mu \mathrm{m}$ column. Working conditions were:

Initial temperature, $100{ }^{\circ} \mathrm{C}$; initial time, $5 \mathrm{~min}$; rate, $20{ }^{\circ} \mathrm{C} \mathrm{min}-1$; final time, $18 \mathrm{~min}$; pressure, $10 \mathrm{psi}$.

Retention times were: $\mathrm{t}_{\mathrm{R}}($ benzaldehyde $)=7.8 \mathrm{~min}$ and $\mathrm{t}_{\mathrm{R}}(1$-phenyl-1-propanol $)=11.9 \mathrm{~min}$. The percentage conversion was determined from the peak areas of products and unreacted benzaldehyde by: $\%$ conversion $=$ [(1-phenyl-1-propanol area) / (1-phenyl-1 propanol area + benzaldehyde area)] x 100.

Conversion percentages were confirmed by ${ }^{1} \mathrm{H}-\mathrm{NMR}$ spectroscopy. The products were dissolved in $\mathrm{CDCl}_{3}$ and run on a Bruker DRX-300 spectrometer at $300 \mathrm{MHz}$. Calculation of conversion\% was made from the areas of the $\mathrm{Ph}-\mathrm{CH}(\mathrm{Et})-\mathrm{OH}$ proton signal of 1-phenyl-1-propanol located at $4.5 \mathrm{ppm}$ and that of the $\mathrm{CHO}$ of benzaldehyde located at $10.0 \mathrm{ppm}$ with respect to TMS.

The enantiomeric excess $(e e \%)$ was estimated on an HP 5890 series II gas chromatograph with an Allchrom plus program and a Supelco $\beta$-Dex $12030 \mathrm{~m} \times 0.25 \mathrm{~mm}$ $\times 0.25 \mu \mathrm{m}$ chiral capillary column at initial temperature, $100{ }^{\circ} \mathrm{C}$; initial time, $10 \mathrm{~min}$; rate, $1{ }^{\circ} \mathrm{C} \mathrm{min}^{-1}$; pressure, 10 psi. Retention times were the following: $\mathrm{t}_{\mathrm{R}}(S-1$-phenyl1 -propanol $)=28.7 \mathrm{~min} ; \mathrm{t}_{\mathrm{R}}(R-1$-phenyl-1-propanol $)=$ $29.7 \mathrm{~min}$.

The $e e \%$ was calculated from the corresponding areas of the signals of the $S$ and $R$ enantiomers of 1-phenyl1-propanol: $e e \%=\mid S$-1-phenyl-1-propanol area $-R$-1phenyl-1-propanol area $\mid /(S$-1-phenyl-1-propanol area + $R$-1-phenyl-1-propanol area) $\times 100$.

The predominant configuration of the products was given by the sign of the optical rotation measured at $20^{\circ} \mathrm{C}$ on a Perkin Elmer PE 241 polarimeter with the literature data: ${ }^{10}$

$\left[\alpha^{\circ}\right]_{\mathrm{D}}(S$-1-phenyl-1-propanol $)=+48^{\circ}$ at $20^{\circ} \mathrm{C}$ and $\left[\alpha^{\circ}\right]_{\mathrm{D}}(R-1$-phenyl-1-propanol $)=-48^{\circ}$ at $20^{\circ} \mathrm{C}$.

\section{Acknowledgments}

The authors acknowledge the financial support of FONDECYT under initiation project 2006 No. 11060463.

\section{References}

1. Noyori, R.; Asymmetric Catalysis in Organic Synthesis, Wiley: New York, 1994.

2. Pu, L.; Yu, H-B.; Chem. Rev. 2001, 101, 757.

3. Paixão, M. W.; Braga, A. L.; Lüdtke; J. Braz. Chem. Soc. 2008 , $19,813$.

4. Soai, K.; Niwa, S.; Chem. Rev. 1992, 92, 833.

5. Hübsher, J.; Barner R.; Helv. Chim. Acta 1990, 73, 1061.

6. Jacobbsen, E. N.; Pfaltz, A.; Yamamoto, H.; Comprehensive Asymmetric Catalysis, Springer: New York, 1999.

7. You, J.-S.; Shao, M.-S.; Gau, H.-M.; Organometallics 2000, 19, 3368.

8. González-Sabín, J.; Gotor, V.; Rebolledo, F.; Tetrahedron: Asymmetry 2006, 17, 449.

9. Parada, J.; Aguirre, P.; Herrera, J.; Pôster, XXVI Jornadas Chilenas de Química, Sociedad Chilena de Química, Concepción, Chile, 2006.

10. Morrison, J. D.; Mosher, H. S.; Asymmetric Organic Reactions; American Chemical Society Books: Washington, DC, 1976. 
11. Pedraza, A.; MSc Dissertation, Universidad de Chile, Chile, 2008.

12. Parada, J.; Herrera, J.; Pedraza, A.; Aguirre, P.; Zolezzi, S.; Pôster, XXVII Jornadas Chilenas de Química, Sociedad Chilena de Química, Chillán, Chile, 2007.

13. Blay, G.; Fernández, I.; Marcos-Aleixandre, A.; Pedro, J. R.; Tetrahedron: Asymmetry 2005, 16, 1207.

14. Parada, J.; Herrera, J.; Aguirre, P.; Zolezzi, S.; Poster, XXI Simposio Iberoamericano de Catálisis (SICAT 2008), Benalmádena-Costa, Málaga, España, 2008.

15. Herrera, J.; MSc Dissertation, Universidad de Chile, Chile, 2006.

16. Balsells, J.; Davis, T. J.; Carroll, P.; Walsh, P.J.; J. Am. Chem. Soc. 2002, 124, 10336.

17. Buriak, J. M.; Osborn, J. A.; Organometallics 1996, 15 , 3161.

18. Blaser, H.U.; Chem. Rev. 1992, 92, 935.
19. Penne. J.S.; Chiral Auxiliaries and Ligands in Asymmetric Synthesis, Wiley: New York, 1995.

20. Diéguez, M. ; Pàmies, O. ; Claver, C. ; Chem. Rev. 2004, 104, 3119.

21. Diéguez, M.; Pàmies, O.; Ruiz, A.; Díaz, Y.; Castillón, S.; Claver C.; Coord. Chem. Rev. 2004, 248, 2165.

22. Collins P.; Ferrier R.; Monosaccharedes: Their Chemistry and Their Roles in Natural Products, Wiley: New York, 1995.

23. Noyori, R.; Kitamura, M.; Angew. Chem., Int. Ed. Engl. 1991, $30,49$.

24. Noyori, R.; Suga, S.; Kawai, K.; Okada, S.; Kitamura, M.; Oguni, N.; Hayashi, M.; Kaneko, T.; Matsuda, Y.; J. Organomet. Chem. 1990, 312, 19.

25. Wu, K.-H.; M.-S. ; Gau. H.-M.; Organometallics 2004, 23, 3368.

Received: May 27, 2008

Web Release Date: November 12, 2008 